\title{
Development of Self-efficacy Skills of School Administrators through Simulation and Micro-teaching Methods ${ }^{\mathrm{i}}$
}

\author{
Dr. Erol Ata \\ Department of Educational Science, Faculty of Education, Amasya University, Turkey
}

Copyright $\bigcirc 2018$ by authors, all rights reserved. Authors agree that this article remains permanently open access under the terms of the Creative Commons Attribution License 4.0 International License

\begin{abstract}
The belief, which includes the ability of doing something effectively, is self-efficacy. In this study, effective learning were intended to provide the participants, by using simulation and micro-teaching techniques from current method and approaches considering internationals standarts in growing school leaders. In this context, the purpose of this study was to train school leaders with high level self-efficacy beliefs, who are successful and contribute to realizing the goals of the school. In line with this aim, a training program lasting for 4 days was designed for selected school administrators candidates in Amasya province of Turkey 22 school administrator candidates were selected from different school levels. A pre-test was conducted on the participants before the training program and their readiness was determined. After the training, a post-test including the topics such as administrator self-efficacy was conducted on the participants. According to the findings, which were achieved after conducting Wilcoxon Signed-Rank in order to test the difference the school administrator self-efficacy beliefs before and after the training, significant differences were found in all dimensions of the self-efficacy scale. The fact that the statistical differences are in favor of pre-test scores means that the training program conducted were effective in the developing the self-efficacy beliefs of school administrators.
\end{abstract}

Keywords Micro-teaching, Simulation, Self-efficacy, Training School Administration

\section{Introduction}

The remarkable changes emerging in recent years have featured educational leadership in terms of educational policies and debates over education. A growing body of literature has investigated the importance of school leaders in increasing student achievement, improving school culture and climate, motivating students, changing and developing teaching and making schools successful [7, 13, $16,18,31,33]$. School leaders today must not only deal with financial issues in schools but must be a good analyst and change expert with society, as well. School leaders also must be able to set school staff into action and employ each instrument [7].

What does a school principal do? What is the importance of school principal? In many circumstances, these questions are brought to the agenda by parents, students, teachers, institutions and principals themselves. The main aim of school principals is to improve teaching and learning. Managing the school is not a preliminary role, but a supportive and instrumental role. A great number of principals seem as if they weren't associated with teaching and learning as the principal works aren't directly related to students. Given that a school principal has lots of tasks to achieve, he/she is expected to a person who needs expertise of stakeholders. Additionally, they must be expert on bring things together, as well. As Gamage ([14] reminds us, school principals have significant distinctive assignments in order to realize teaching and learning effectively as a manager.

School principals must:

1-Develop a shared vision for the school and become effective on this.

2-Develop strategies so as to include stakeholders to create a shared vision and determine aims.

3-Display leadership in order to realize the programmes.

4-Form the patterns and processes in which the coordination can be achieved to conduct the programmes.

5-Procure necessary resources to support the organization and distribute them.

6-Represent the organization and become a conciliator.

7-Scale the effectiveness of the organization and manage it.

Throughout the past ten years, the roles of the school principals have shifted remarkably. Indeed, during this 
period, the role of the principals has become even more difficult so much so that the result has been role ambiguity [23]. In another study, Murphy and Louis [29] found that school principals were moving toward a new leadership role defined by a wide range of management responsibilities, cultural leadership and direct educational leadership. The behaviours which must be displayed by school principals can be listed as having team structures at the schools, school improvement objectives, provide reliable data on student performance, creating a sustainable school. Leithwood, Jantzi and Steinbach [20] found that school leaders' time was devoted to building consensus around organizational goals and 'assisting staff in developing consistency between school visions and both group and individual goals'. Administrating a school is a complex task which necessitates extraordinary knowledge and skills. Today's schools present a variety of social and economic problems, so the responsibilities of the school administrators have been boosted [21]. In their studies on principals' time use, Bezzina, Paletta and Alimehmeti [5] obtained some striking findings, which reveal that principals' assignments were often determined by different things and fragmentation. They often dealt with the tasks in short time intervals and the related tasks usually occur spontaneously out of the milieu of the daily life of the school. It was found in the study that a great deal of time was spent on "putting out fires" as the school principals had to deal with situations arising throughout the school day. According to International Successful School Principalship Project (ISSPP) results, effective school leaders' behaviours can be listed as: 1-Setting directions: identify the school's vision, establish clear and well-defined school goals associated with performance expectations, and improve achievement of students; 2-Developing people: professional development of teachers, intellectual stimulation, support, and consideration;3-Refining and aligning the organization: building a collaborative culture that allows the distribution of leadership; and 4-Improving the teaching and learning program: focusing on the coordination, development, and monitoring of the curriculum [10].

The increasing importance of school leadership also brings about the necessity of growing school principals for this responsibility. Self-efficacy is a key phenomenon in the development of educational leaders' characteristics and skills. When school administrators have high level self-efficacy beliefs, they become successful. Those with low self-efficacy beliefs, on the other hand, fail to realize organizational objectives [24]. The traditional ways of selecting and preparing school principals doesn't yield expected results. It is therefore important to address school principalship as a professional occupation scientifically and to improve it [15].

Self-efficacy can be defined as a personal judgment of an individual on the ability related to whether he/she can perform a task satisfactorily, by planning the orders of the actions. In other words, it is the evaluation of the capacity which is based on the perceptions to realize a task [17].

Perceived self-efficacy is among the most important determiners of leading behaviours, making decisions in the social system, noticing the opportunities and threats, forming expectations on human behaviors. Self-efficacy has an influence on working life in a different way. Those with low self-efficacy levels don't enjoy their occupations and cannot even focus on the simplest tasks [4]. Those with high self-efficacy levels, on the other hand, enjoy the tasks involving innotavative and productive tasks. Transmitting the experiences to those who are beginners in the organizations, helping one another effectively, giving feedback so as to encourage staff and realizing their job satisfactions can develop their self-efficacy skills. The resources which can be employed in order to develop self-efficacy belief can be listed as [37]:

1-Expertise Experiences: Past achievements and experiences develop the individuals' self-efficacy beliefs, while failures cause some hesitations. Those with high self-efficacy tend to be more resilient in the event of failures. Rather, they tend to try again and move forward.

2-Taking Role Model and Observed Experiences: Individuals draw some conclusions as to their self-efficacy by observing and comparing the environment.

3-Social Persuading: The suitable approaches and being aware of the realities lead individuals to display resilient efforts to achieve.

4-Psychological and Emotional Circumstances: The judgments of the individuals on their abilities lead their efforts and initiate them to set out, whereas feeling pressure may have adverse effects on their efforts to be shown for the tasks.

When addressed in general, those with high self-efficacy tend to be better motivated for a goal and spend much more efforts than those who lack of self-efficacy belief. This situation reveals that leaders with high self-efficacy have key skills and they are effective ones. Increasing self-efficacy beliefs of educational leaders are important in that they need these beliefs in order to be successful in their occupations. Those with high self-efficacy become successful in their professions, as well. Those lack of self-efficacy, on the other hand, cannot display expected efforts to complete a task [22]. It is well-documented in literature $[2,11,25,35,37]$ that self-efficacy has an utmost importance in leadership. As Munoz, Rinehart and Winter [28] remind us, self-judgments of the individuals as to their capacity affect their future capacity needed for a task more than their real knowledge and skill levels. It is common knowledge that self-efficacy is a significant predictor of a school principal to be appointed. Bandura [4] highlights that the judgments of individuals as to their own capacities affect them in terms of motivating them and determining targets. Munoz, Rinehart and Winter [28] also notes that self-efficacy belief is a significant predictor of recruiting school administrators. 
Moran and Gareis [27] note that principal self-efficacy is necessary for leading the groups to realize the objectives. Concurs well with Louis at al. [22], who suggests that self-efficacy is also needed to perform effective communication in order to yield a high performance. Versland [36] put forwards that principalship preparation programmes must include steps which enable the candidates to gain necessary skills and to build their self-efficacy. Within this context, principal preparation programmes can give expected results to form experiences and to develop self-efficacy.

Employing simulating and micro teaching techniques provide permanent learning. Simulation technique is the realization of a problem, a situation, an event or a revival of the material and the removal of potentially dangerous situations. Through the simulation, the individual reveals his knowledge and skills [34]. Micro teaching technique is a laboratory teaching method aimed at simplifying the complexity of normal learning and teaching processes. This technique can be used to provide a wider experience for teacher candidates under normal circumstances, but it can also be used in effective school leader training programs. In this technique, the applications made by taking the applications made into the video records are revised and new evaluations can be made. Micro-teaching also reveals the relationship between theory and practice. In micro teaching technique, observation, evaluation, written and verbal communication are available. [9, 19, 30].

With these techniques, studies that are similar to real school experiences can be analyzed with micro teaching method and administrative candidates can have the knowledge and skills required by the standards of school administration. The ISLLC Educational Leadership Policy standards have been taken into account in assessing the standards for school leadership. These standarts include the knowledge and skills aimed to make administrators to have in USA [8].

Educational Leadership Policy Standards (ISLLC) can be listed as: Effective school leaders;

1-Advocate a qualified education for each student, put into practice a shared vision and develop core values

2-Act professionally

3-Attach great importance to equal opportunity and cultural differences

4-Develop and implement convenient curriculum systems, a better teaching environment as well as assessment systems

5-Accomplish tasks inclusively and thoroughly

6-Develop the occupational capacity of staff and their experiences

7-Encourage professional teachers and learning communities

8-Involve parents and society in a meaningful way

9-Manage the resources and perform the works accordingly
10-Continuously tend to give effort in pursuit of improving the education so that they can increase student achievement and provide a high quality education.

Within this framework, this study was planned towards the development of self-efficacy levels of school principals through simulation and micro teaching techniques as well as didactic and discussion methods. The implementations conducted by means of these techniques were revised and the necessary assessments were performed. The aim of this study is to determine whether these implementations are effective in development of self-efficacy beliefs of principals or not.

\section{Materials and Methods}

A semi-experimental research design was employed in this study. Pre-test and post-test were conducted on participants of the study.

\subsection{Population and Sample}

The population of the study is composed of school administrators in Amasya. A total of 22 school administrators were recruited for the study. The participants working in Amasya province of Turkey took part in the research voluntarily.

\subsection{Data Collection}

This study was conducted with the collaboration of Amasya Province National Directorate of Education between 23-26.01.2018 within the context of Amasya University Scientific Research Project Fund Program. The academicians in Amasya University were recruited as trainers in the study. The subjects listed below were included during the project conducted in order to develop school administrators' self-efficacy according to The 2015 Professional Standards for Educational Leaders [8]: 1-Effective meeting management; 2-Effective communication, team work and the traits of effective individuals; 3-Effective time management; 4-Understanging teaching and learning processes; 5-Benefitting from resources in society and ethical leadership; 6-Developing a school climate.

The official permissions were obtained from Amasya Province National Education Directorate according to cooperation protocol between Amasya University and Amasya Province National Education Directorate, prepared for the training. A total of 22 school administrators were recruited for this study among 30 schools from different school levels. The participants were provided with necessary explanations before the study. Before the practice in the study, a pre-test was employed in order to measure the self-efficacy beliefs of the participants and their readiness level was determined. After the practice, 
a post-test related to administrators' self-efficacy and a questionnaire about the achievements of the training were employed. Personal privacy and being volunteer were given importance during surveys. The surveys were distributed in closed files and were obtained anonymously. In order to determine the self-efficacy levels of the participants, "School Administrators Self-efficacy Scale (SASS)" developed by to Ata [1] was conducted. SASS has 48 items, distributing 8 sub-dimensions. The scale was developed by the researcher and reliability and validity studies were conducted. The calculated Cronbach Alpha reliability coefficient of the scale was .988 .

\subsection{Data Analysis}

The data obtained from the participants through SASS pre-test and post test was analysed via SPSS 22 Software Package Program. Since the participant numbers were limited to a small group $(n=22)$, Wilcoxon signed-rank test [6] was employed in order to test if there is a statistically significant difference between self-efficacy scores before and after the training. Additionally, a questionnaire with multiple choice questions was used to see what achievements they have gained and the results are demonstrated in Table 3.4.

\section{Findings}

The demographic information on participants can be seen in Table 3.1. Accordingly, the participants were distributed as $13,6 \%$ female $(n=3)$ and $87 \%$ as male $(n=$ 19). $45,5 \%$ of the participants were appointed through exam, while the rest of them were selected via assignment.
Table 3.1. Demographic Information on Participants

\begin{tabular}{|l|c|c|}
\hline Traits & $\mathrm{f}$ & $\%$ \\
\hline Gender & 3 & 13,6 \\
Female & 19 & 87,4 \\
Male & & \\
\hline Work experience in current school & 17 & 77,3 \\
1-5 years & 3 & 13,6 \\
6-10 years & - & - \\
11-15 years & 1 & 4,5 \\
16-20 years & 1 & 4,5 \\
21 years and above & & \\
Work experience as administrator & 14 & 63,6 \\
1-5 years & 3 & 13,6 \\
6-10 years & 1 & 4,5 \\
11-15 years & 1 & 4,5 \\
16-20 years & 3 & 13,6 \\
21 years and above & & \\
Work experience in teaching & 1 & 4,5 \\
1-5 years & 1 & 4,5 \\
6-10 years & 6 & 27,3 \\
11-15 years & 7 & 31,8 \\
16-20 years & 7 & 31,8 \\
21 years and above & 10 & 45,5 \\
Exam & & 54,5 \\
Appointment & & \\
\hline Assignment Styles & & \\
\hline
\end{tabular}

The data related to pre-test and post-test results were analysed through Wilcoxon singed-rank test according to the self-efficacy total scores and the results are demonstrated in Table 3.2 As shown in Table 3.2, according to the analysis results which were obtained via Wilcoxon singed-rank test from 22 school administrators' pre-test and post-test scores; there was a statistically significant difference between pre-test and post-test scores of the participants in all sub-dimensions $(z=-3,964$, $p<0,05)$. The fact that the difference was in favor of negative ranks (pre-test score) means that the training was effective in developing self-efficacy.

Table 3.2. Wilcoxon Singed-Rank Test Result of Self-Efficacy Total Score

\begin{tabular}{|c|c|c|c|c|c|c|}
\hline Variable & Pre-test - Post-test & N & Mean rank & Sum of ranks & Z & $\mathrm{p}$ \\
\hline \multirow{3}{*}{ Self-Efficacy Total Score of School Administrators } & Negative ranks & 1 & 1,5 & 1,5 & $-3,964$ & 0,000 \\
\cline { 2 - 7 } & Positive ranks & 20 & 11,48 & 229,50 & & \\
\cline { 2 - 7 } & No difference & 1 & & & & \\
\hline
\end{tabular}

*Based-on negative ranks 
Table 3.3. Wilcoxon Singed-Rank Test Result of Sub-dimensions

\begin{tabular}{|c|c|c|c|c|c|c|c|}
\hline & Sub-dimension & Pre-test - & $\mathrm{N}$ & Mean & Sum of & $\mathrm{Z}$ & $\mathrm{p}$ \\
\hline & & Negative ranks & 2 & 3,50 & 7 & $-3,881$ & 0,000 \\
\hline 1 & Educational leadership and staff development & Positive ranks & 20 & 12,30 & 246 & & \\
\hline & & No difference & 0 & & & & \\
\hline & & Negative ranks & 3 & 3,17 & 9,50 & $-3,571$ & 0,000 \\
\hline 2 & Developing school climate & Positive ranks & 17 & 11,79 & 200,50 & & \\
\hline & & No difference & 2 & & & & \\
\hline & & Negative ranks & 5 & 4,60 & 23 & $-3,064$ & 0,002 \\
\hline 3 & Collaboration with society & Positive ranks & 15 & 12,47 & 187 & & \\
\hline & & No difference & 2 & & & & \\
\hline & & Negative ranks & 1 & 2,50 & 2,50 & $-3,833$ & 0,000 \\
\hline 4 & Making decision with legal and ethical considerations as well & Positive ranks & 19 & 10,92 & 207,50 & & \\
\hline & & No difference & 2 & & & & \\
\hline & & Negative ranks & 2 & 2,5 & 5 & $-3,847$ & 0,000 \\
\hline 5 & Managing resources and services & Positive ranks & 19 & 11,89 & 226 & & \\
\hline & & No difference & 1 & & & & \\
\hline & & Negative ranks & 3 & 6,33 & 19 & $-3,218$ & 0,001 \\
\hline 6 & Use of social resources & Positive ranks & 17 & 11,24 & 191 & & \\
\hline & & No difference & 2 & & & & \\
\hline & & Negative ranks & 2 & 5,50 & 11 & $-3,645$ & 0,000 \\
\hline 7 & Communication in different environments & Positive ranks & 19 & 11,58 & 220 & & \\
\hline & & No difference & 1 & & & & \\
\hline & & Negative ranks & 2 & 4,25 & 8,50 & $-3,228$ & 0,001 \\
\hline 8 & Developing school vision & Positive ranks & 15 & 9,63 & 144,50 & & \\
\hline & & No difference & 5 & & & & \\
\hline
\end{tabular}

*Based-on negative ranks

The data related to pre-test and post-test results were analysed through Wilcoxon singed-rank test according to the sub-dimensions separately and the results are demonstrated below: In this context, the results on sub-dimensions "Educational leadership and staff development, Developing school climate, Collaboration with society, Making decision with legal and ethical considerations as well as based-on information, Managing resources and services, Use of social resources, Communication in different environments and developing "school vision" are demonstrated in Table 3.3. According to Table 3.3, the analysis results which were obtained via Wilcoxon singed-rank test from 22 school administrators' pre-test and post-test scores; there was a statistically significant difference between pre-test and post-test scores of the participants in self-efficacy's all sub-dimensions ( $\mathrm{z}=$ $-3,881, p<0,05 ; \mathrm{z}=-3,571, \mathrm{p}<0,05 ; \mathrm{z}=-3,064, \mathrm{p}<0,05 ; \mathrm{z}=$ $-3,833, p<0,05 ; \mathrm{z}=-3,847, \mathrm{p}<0,05 ; \mathrm{z}=-3,218, \mathrm{p}<0,05 ; \mathrm{z}=$ $-3,645, p<0,05 ; z=-3,228, p<0,05)$. The fact that the difference was in favor of negative ranks (pre-test score) means that the training was effective all sub-dimension.

Table 3.4 (the participants can circle more than once). The results were assessed through Multiple Response test. Accordingly, the participants revealed the achievements they had gained by means of the survey with 28 items. The most responded items are listed as: Active listening skills $\% 90$, being able to show empathy $\% 90$, developing school climate $\% 86$, features of an effective meeting $\% 86$, Conflict management and decision-making process $\% 81$, The importance of human relations in school administration \%77, The importance of effective school administrators \%77, The importance of emotional intelligence in school administration, \%77, The basic problems encountered in meetings, \%77, Being able to Ben-Language in communication, \%77. The results of multiple response test demonstrate that the achievements displayed confirm that these are effective in developing self-efficacy skills of school administrators. 
Table 3.4. Results of Multiple Response Test

\begin{tabular}{|c|c|c|}
\hline Achievement & $\begin{array}{l}\text { The number of } \\
\text { Preference }\end{array}$ & $\begin{array}{l}\text { The Percentage of the Number of } \\
\text { Preference } \%\end{array}$ \\
\hline 1-Developing school culture & 16 & 72 \\
\hline 2- Conditions of developing school climate & 19 & 86 \\
\hline 3-The importance of human relations in school administration & 17 & 77 \\
\hline 4-The importance of effective school administrators & 17 & 77 \\
\hline 5-The importance of emotional intelligence in school administration & 17 & 77 \\
\hline 6-How does learning take place? & 12 & 52 \\
\hline 7-The relation between school and environment in learning & 7 & 31 \\
\hline 8- Instructional Leadership & 11 & 50 \\
\hline 9- The traits of effective meetings & 19 & 86 \\
\hline 10-The structure of educational programmes & 12 & 54 \\
\hline 11-The necessary pathways to make effective decisions & 16 & 72 \\
\hline $\begin{array}{l}\text { 12-The duties and responsibilities of school administrators as meeting } \\
\text { moderators }\end{array}$ & 17 & 77 \\
\hline 13-Utilisation of legal principles supporting equality in education & 12 & 54 \\
\hline $\begin{array}{l}\text { 14-The utilisation pathways of benefitting from local resources in } \\
\text { school administration }\end{array}$ & 16 & 72 \\
\hline 15-Problem solving methods based on ethical principles & 16 & 72 \\
\hline 16-Ethical principles in administration & 16 & 72 \\
\hline 17-Conflict management and decision-making process & 18 & 81 \\
\hline 18- The basic problems encountered in meetings & 17 & 77 \\
\hline 19- Making decisions in school and implementing & 16 & 72 \\
\hline 20- Leadership in different educational environments & 12 & 54 \\
\hline 21-Resolving possible conflict in school & 14 & 63 \\
\hline 22- Being able to Ben-Language in communication & 17 & 77 \\
\hline $\begin{array}{l}\text { 23-The duties and responsibilities of school administrators as meeting } \\
\text { moderators }\end{array}$ & 14 & 63 \\
\hline 24-Active listening skills & 20 & 90 \\
\hline 25-Being able to show empathy & 20 & 90 \\
\hline $\begin{array}{l}\text { 26-Being able to develop positive communication with business and } \\
\text { social institutions }\end{array}$ & 14 & 63 \\
\hline 27-Effective time management & 16 & 72 \\
\hline 28-Time traps & 15 & 68 \\
\hline
\end{tabular}

\section{Discussion and Result}

This paper was to contribute to the development of self-efficacy skills of deputy school administrators within the scope of a scientific project and to prepare them as more effective school leaders. In line with this aim, simulation and micro-teaching techniques in which similar circumstances can be experienced virtually and the subject analyses can be made were employed. As a result of 4-day training, it was intended to develop self-efficacy skills of school administrators. Taking role model, psychological and emotional circumstances, expertise experiences and suitable and reasonable approaches which are suitable for individual capacities are effective methods and are sources of self-efficacy. These kinds of trainings may enhance the efforts and courage of the participants. At this precise point, it was found that there was statistically significant difference between pre-test and post-test scores related to self-efficacy skills of school administrators according to Wilcoxon signed-rank test result. It is therefore important to suggest that the training directed to school administrators had a significant effect on development of self-efficacy skills. This result demonstrates that self-efficacy is a key component of preparing and developing school administrators.

Bandura [2, 3]. defines self-efficacy as having the confidence that one can successfully adopt behaviours and actions which will lead to the achievement of certain goals and outcomes. On the other hand, Schermerhorn, Hunt, and Osborn [32, p.123] considers it as "an individual's belief about the likelihood of successfully completing a specific task". Wood and Bandura [38, p.413]. also note that people 
must have "a robust sense of personal efficacy to sustain the productive attentional focus and perseverance of effort needed to succeed". Moran and Gareis [26] note that principals' efficacy beliefs to influence the level of effort and persistence they put forth in their daily work, as well as their resilience in the face of setbacks. Duran and Yildirim [12] found that school administrators' happiness level affects their Administrative skills. The more they feel happier, the more they show competences in administrative positions. Besides, as they feel more competent, their happiness levels will also increase. Armed with compelling new evidence about school administrators who are lack of self-efficacy cannot show necessary efforts [24]; it can be argued that self-efficacy is a preliminary condition of leadership $[25,35,37]$ and affects the targets and motivation levels of individuals [4] as well as a strong predictor of self-efficacy which is important for selecting school administrators [27]. Dimmock \& Hattie [11]. revealed that self-efficacy can be a powerful mediator in understanding the reactions to change. Principals with high self-efficacy are more likely to accommodate and cope with change, and possibly accrue more benefits for their teachers and students as a consequence of restructuring. These compelling evidences concur well with this study which is considered as important in terms of presenting new insights into preparing and developing school administrators. The present findings might help to have important implications for several courses of action in order to boost self-efficacy skills of school administrators. That is to say, school administrators can perform professionally and effectively when provided with proper training and professional development opportunities. An additional important implication is that it gives satisfying results to employ innovative methods to develop school administrators' skills. Future research may explore the same hypothesis model with larger research kits. Future studies on the current topic are therefore recommended in order to contribute to the existing literature related to school leadership and school development.

\section{REFERENCES}

[1] Ata, E. Okul Yöneticilerinin Öz Yeterlik İnançları İle Etkili Okul Liderliği Arasındaki İlişki. Yayınlanmamış Doktora. Tezi. Gazi Üniversitesi, Eğitim Bilimleri Enstitüsü. 2015.

[2] Bandura, A. Self-Efficacy: Toward A Unifying Theory Of Behavioral Change. Psychological Review, 84(2), 191-215. Online Available: http:// www.Uky.edu/ eushe2/ Bandura/ Bandura1977PR.pdf. 1977.

[3] Bandura, A. Self-Efficacy Mechanism in Human Agency. American Psychologist, 37, 122-147.7. 1982.

[4] Bandura, A. Cultivate Self-Efficacy for Personal and Organizational Effectiveness. Handbook of Principles of Organization Behavior. (Ed. Locke, E. A.). Oxford, UK:
Blackwell. Online Available: www.uky.edu/ eushe2/ Bandura/BanduraPubs.html. 2009.

[5] Bezzina, C., Paletta, A. \& Alimehmeti, G. What Are School Leaders in Italy Doing? An Observational Study. Educational Management Administration \& Leadership, 46(5), 841-863. doi: 10.1177/1741143217694896. 2018.

[6] Can, A. SSPS İle Nicel Veri Analizi. Ankara, Pegem. 2014.

[7] CCSSO. Educational Leadership Policy Standards. Online Available:

http://www.ccsso.org/Documents/2008/Educational_

[8] Leadership_Policy_Standards_2008.pdf. 2008.

[9] CCSSO. The 2015 Professional Standards for Educational Leaders. Online Available: https://ccsso.org/ resourcelibrary/professional-standards-educational-leaders. 2015.

[10] Demirel, Ö. Öğretme Sanat1. Ankara, Pegem. 2004.

[11] Day, C., \& Leithwood, K. (Eds.). Successful School Leadership in Times of Change. Dordrecht: Springer-Kluwer. 2007.

[12] Dimmock, C., \& Hattie, J. School Principals' Self-Efficacy and Its Measurement in a Context of Restructuring. School Effectiveness and School Improvement, 7(1), 62-75. 1996.

[13] Duran, A. \& Yildirim, N. The Relationship between School Administrators' Happiness Levels and Their Self-Efficacy Levels. International Journal of Higher Education, 6(4), 210-228. 2017.

[14] Fullan, M.G. Successful School Improvement. Philadelphia: Open University Press, 1997.

[15] Gamage, D. T. Professional Development for Leaders and Managers of Self-Governing Schoolls. Australia, Springer. 2006.

[16] Güçlü, N. Eğitim Yöneticisi Olarak Okul Yöneticisi. Milli Eğitim Dergisi, 134, 50-54. 1997.

[17] Harris, A. Effective Leadership in Schools Facing Challenging Contex. School Leadership and Management, 22(1), 15-26. 2002.

[18] Hoy, W. K. \& Miskel, C. Eğitim Yönetimi (Turan, S. Çev. Edi.). Ankara: Nobel. 2010.

[19] Krüger, M. The Big Five School Leadership Competences in the Netherlands. School Leadership and Management, 29(2), 109-127. 2009.

[20] Küçülahmet, L. Öğretimde Planlama ve Değerlendirme. Ankara: Nobel. 2008.

[21] Leithwood, K., Jantzi, D. \& Steinbach, R. Changing Leadership for Changing Times. Philadelphia, PA, Open University Press. 1999.

[22] Lupton, R. Secondary School in Disadvantaged Areas. London, Thesis. 2003.

[23] Louis, K. S. at all. Learning from Leadership: Investigating the Links to Improved Student Learning. Final Report of Research to the Wallace Foundation. Online Available: https://s3.amazonaws.com/academia.edu.documents/853014 1/ learning-from- leadership_final-report_march-2010.pdf? 2010 . 
[24] Marsh, D. D. \& LeFever, K. School Principals as Standarts-Based Educational Leaders. Educational Management Administration \& Leadership, 32(4), 387-404. doi: 10.1177/1741143204046494. 2004.

[25] McCollum, D. L. \& Kajs, L. T. Examining the Relationship between School Administrators' Effficacy and Goal Orientations. Educational Research Quarterly, 32 (3), 29-46. 2009.

[26] McCorrmick M. J. Self-Efficacy and Leadership Effectiveness: Applying Social Cognitive Theory to Leadership. The Journal of Leadership Studies, 8(1), 22-33. 2001.

[27] Moran, M., T. \& Gareis, C. R. Principals' Sense of Efficacy. Journal of Educational Administration, 42(5), 573-585. doi:10.1108/09578230410554070. 2004.

[28] Moran, M., T. \& Gareis, C. R. Cultivating Principals' Sense of Efficacy Supports That Matters. Presented at The Annual Meeting of The University Council for Educational Administration. Nashville. Online Available: www.ucea.org/storage/ conventation. 2005, November

[29] Munoz, Rinehart \& Minter, Principal Recruitment. Journal of Personnel Evaluation. 16(2). 129-141. 2002.

[30] Murphy, J. \& Louis, K. S. Reshaping the Principalship: Insights from Transformational Reform Efforts. Thousand Oaks, CA, Corwin Press. 1994

[31] Remesh, A. Microteaching, An Efficient Technique for Learning Effective Teaching. Journal of Research Medicine Sciences, 18(2): 158-163. 2013.

[32] Robinson, V., Lloyd, C. \& Rowe, K. The Impact of Leadership on Student Outcomes: An Analysis of The Differential Effects of Leadership Types. Educational Administration Quarterly,44: 5, 635-674. 2008.

[33] Schermerhorn, J.R., Hunt, J.G., \& Osborn, R.N. Managing Organizational Behavior (5th ed.). New York: John Wiley. 1994.

[34] Supovitz, J., Sirinides, P. \& May, H. How Principals and Peers Influence Teaching and Learning. Educational Administration Quarterly, 46(1),31-56. 2010.

[35] Sünbül, A. M. Öğretim İlke Yöntemleri. Konya. Eğitim Yayınevi. 2014.

[36] Osterman, K. \& Sullivan, S. New Principals in an Urban Bureaucracy: A Sense of Efficacy. Journal of School Leadership, 6 (6), 661-691. 1996.

[37] Versland, T. M. Exploring Self-Efficacy in Education Leadership Programs: What Makes The Difference? Journal of Research on Leadership Education, 11(3) 298-320. 2016.

[38] Wood, R. \& Bandura, A. Social Cognitive Theory of Organizational Management. The Academy of Management Review,14(3), 361-384. 1989.

[39] Wood, R.E., \& Bandura, A. Impact of Conceptions of Ability on Self-Regulatory Mechanism and Complex Decision Making. Journal of Personality and Social Psychology, 56, 407-415. 1989.

i 1. This research was supported by Amasya University Scientific
Research Project Fund Program.

2. This paper was orally presented at The International Conference of Engineering, Science and Mathematics Education (ICESME'18) held between 1-2 September in St. Petersburg. 